\title{
EVALUATION OF THE ANTI-ARTHRITIC EFFECT OF STERCULIA TRAGACANTHA (LINDL.) LEAF EXTRACT IN RATS
}

\author{
${ }^{1}$ Udegbunam Rita Ijeoma, ${ }^{2}$ Nwaehujor Chinaka Onyebuchi \\ and ${ }^{1}$ Udegbunam Sunday Ositadimma
}

\begin{abstract}
${ }^{1}$ Department of Veterinary Surgery, Faculty of Veterinary Medicine, University of Nigeria, Nsukka, Enugu State, Nigeria
${ }^{2}$ Department of Biochemistry, Faculty of Basic Medical Sciences, University of Calabar, P.M.B. 1115 Calabar, Nigeria
\end{abstract}

Received 2013-08-28; Received 2013-09-25; Accepted 2014-03-11

\begin{abstract}
Sterculia tragacantha leaves for years have been used by traditional healers in eastern Nigeria in the treatment of arthritis, edema, gout, whitlow and cold. The aim of this study was to evaluate the folkloric claims of Sterculia tragacantha leaf extract in relieving arthritic conditions. The effects of Sterculia Tragacantha methanol leaf Extract (STEX) on formaldehyde and adjuvant-induced arthritis were studied in rats. Paw thickness, White Blood Cell Count (WBC) count, Packed Cell Volume (PCV), Haemoglobin Concentration (HB), Erythrocyte Sedimentation Rate (ESR), lipid peroxidation, Super Oxide Dismutase (SOD) activity and catalase activity were studied post induction of arthritis. In both formaldehyde and adjuvant-induced arthritis studies, mean paw thickness in animals given $300 \mathrm{mg} \mathrm{kg}^{-1}$ STEX was significantly $(\mathrm{p}<0.05)$ lower on days 7 and 14 compared to that of normal saline group. Mean WBC of 100 and $300 \mathrm{mg} \mathrm{kg}^{-1} \mathrm{v}$ STEX groups were significantly $(\mathrm{p}<0.05)$ lower than that of normal saline group. Mean ESR of normal saline and $100 \mathrm{mg} \mathrm{kg}^{-1}$ STEX groups were significantly ( $<<0.05$ ) faster than ESR of $300 \mathrm{mg} \mathrm{kg}^{-1}$ group. Mean MDA level of $300 \mathrm{mg}$ $\mathrm{kg}^{-1}$ STEX group was similar to that of non-arthritic group while mean SOD levels of 300 and $100 \mathrm{mg} \mathrm{kg}^{-1}$ STEX groups were significantly $(\mathrm{p}<0.05)$ higher than that of normal saline group. Mean catalase level of 100 and $300 \mathrm{mg} \mathrm{kg}^{-1}$ STEX groups were significantly $(\mathrm{p}<0.05)$ higher compared to that of normal saline group. These results show that STEX exhibited potent anti-arthritic activity.
\end{abstract}

Keywords: Arthritis, Hematology, Anti-Oxidant, Edema, Freund Adjuvant, Formaldehyde

\section{INTRODUCTION}

Joint diseases are broadly classified as inflammatory or non-inflammatory disorders (Halliwell and Gorman, 1989). Degenerative joint disease (or osteoarthritis) is a non-inflammatory joint disorder while inflammatory diseases of the joint include feline progressive polyarthritis, lupus polyarthritis, idiopathic non erosive arthritis and rheumatoid arthritis (Todhunter and Johnston, 2003; Hegen et al., 2008). Rheumatoid Arthritis (RA) is a chronic auto immune-mediated disease which affects humans and animals (Kahn, 2005; Kaur et al., 2012).
This joint disorder also affects tissues and organs such as the heart, lungs, eye and neuromuscular system (Mahajan et al., 2010). In the joint, RA is characterized by profuse inflammatory reaction in the synovial membrane and subchondral bone which results in progressive erosion of articular cartilage and synovitis (Hegen et al., 2008; Kaur et al., 2012). In advanced cases, ankylosis, subluxation, soft tissue destruction, disuse osteoporosis and pain may be noticed (Halliwell and Gorman, 1989; Goldring and Goldring, 2006).

There is no known cure for RA but several drugs such as anti-inflammatory and disease modifying anti-

Corresponding Author: Nwaehujor Chinaka Onyebuchi, Department of Biochemistry, Faculty of Basic Medical Sciences, University of Calabar, P.M.B. 1115 Calabar, Nigeria Tel: +2348035450300 
rheumatoid drugs are used in mono or combination therapies to inhibit the disease process (Makinen et al., 2007; Zhao et al., 2006; Mottonen et al., 2006). However, prolonged use of these drugs is associated with deleterious side effects such as gastric ulceration, haemorrhage, anemia and kidney dysfunction (Lin et al., 2006; Buhroo and Baba, 2006; Kyei et al., 2012). Thus in recent times, researches have been directed towards the use of biologics (Ruggiero et al., 2009) and plantderived drugs in the treatment of RA (Woode et al., 2009; Kaithwas and Majumdar, 2010).

Several plants such as aloe barbadensis (Josheph and Raj, 2010), actaea racemosa (Bang et al., 2009), caloptropis procera (Vaidya, 2006), parlisota hirsuta (Woode et al., 2009) and linum usitatissimum (Kaithwas and Majumdar, 2010) have shown promising treatment option for rheumatoid arthritis. Traditionally, decoctions made from leaves, bark and seeds of Sterculia tragacantha (family: Sterculiaceae) tree are used in the treatment of arthritis, edema, gout and whitlow (Iwu, 1993). Recently the methanol extract of $S$. tragacantha extract was reported to possess analgesic, anti-inflammatory and in vitro anti-oxidant effects (Udegbunam et al., 2011). Therefore bearing in mind the antioxidant, analgesic and anti-inflammatory effects of $S$. tragacantha and its use in traditional medicine in the management of arthritis, we considered it worthwhile to investigate its anti-arthritic effect.

\section{MATERIALS AND METHODS}

\subsection{Plant Material}

Fresh leaves of $S$. tragacantha were collected in February, 2012 and authenticated by a taxonomist at the Biodiversity Development Centre (BDCP) Nsukka. The leaves were air dried, pulverized and cold macerated in $80 \%$ methanol for $48 \mathrm{~h}$ at $37^{\circ} \mathrm{C}$ with intermittent shaking every $2 \mathrm{~h}$. After $48 \mathrm{~h}$ the extract was filtered and evaporated to dryness in a rotary evaporator to obtain an extract (yield: 12.0\%). Previously, phytochemical analysis of methanol extract of this plant revealed the presence of alkaloids, flavonoids, tannins, glycosides and saponins (Udegbunam et al., 2011). Doses used in this study were selected based on previous acute toxicity and anti-inflammatory studies (Udegbunam et al., 2011).

\subsection{Formaldehyde-Induced Arthritis}

Non-immunological arthritis was induced in four groups $(n=5)$ of rats by sub plantar injection of $0.1 \mathrm{~mL}$ freshly prepared $2.5 \%$ formaldehyde (Seyle, 1949) on day 1 and repeated on day 3 . Groups 1 and 2 received 100 and $300 \mathrm{mg} \mathrm{kg}^{-1}$ body weight (b.w) S. Tragacantha methanol leaf Extract (STEX) orally (p.o) while groups 3 and 4 received $5 \mathrm{mg} \mathrm{kg}^{-1}$ b.w piroxicam (i.m) and normal saline $\left(1 \mathrm{mg} \mathrm{kg}^{-1}\right.$, p.o) $1 \mathrm{~h}$ before arthritis induction. The extract and piroxicam were administered once daily for a period of 10 days. The paw thicknesses of rats were measured on days $0,3,5,7$ and 10 using a venire caliper. The edema component of arthritis was estimated by calculating the difference between day 0 paw thicknesses and paw thicknesses at the various time points. Blood samples were collected from retro orbital plexus on days $0,3,7$ and 10 for total white blood cell count (Bain et al., 2012). On day 10, rats were euthanized and paw tissues collected to determine Malondialdehyde (MDA) level as well as Superoxide Dismutase (SOD) and Catalase (CAT) activities in rat paw tissues. MDA was determined as described by Ohkawa et al. (1979), SOD activity was estimated using the procedure of Sun et al. (1988) while CAT was assayed as described by Sinha (1972). MDA, SOD and CAT levels in paw tissues of a non-arthritic/normal group (group 5) were also studied and compared with those of the arthritic/treatment groups.

\subsection{Freund Adjuvant (CFA) Induced Arthritis}

Immunological arthritis was induced in rats according to the method of Newbould (1963). The left foot pad of each rat was injected subcutaneously with $0.05 \mathrm{ml}$ Freund's adjuvant complete (Sigma Aldrich, Germany). Animals in groups 1, 2, 3 and 4 received $100 \mathrm{mg} \mathrm{kg}^{-1}$ b.w STEX, $300 \mathrm{mg} \mathrm{kg}^{-1}$ b.w STEX, $5 \mathrm{mg} \mathrm{kg}^{-1}$ b.w piroxicam and $1 \mathrm{~mL} \mathrm{~kg}^{-1}$ b.w normal saline $24 \mathrm{~h}$ respectively before adjuvant injection. The treatments were re-administered once daily for 28 days. The left paw and tarso-metatarsal joint thicknesses were measured on days $3,7,14,21$ and 28 post induction of arthritis using a venire caliper. The edema component of arthritis was estimated by calculating the difference between day 0 paw thicknesses and paw thicknesses at the various time points. On day 28, blood was collected to determine the Packed Cell Volumes (PCV), Haemoglobin Concentrations (HB), red Blood Cell Counts (RBC), White Blood Cell counts (WBC) and Erythrocyte Sedimentation Rates (ESR) of rats. PCV was determined by the microhaematocrit method, HB was determined by the cyanmethaemoglobin method, RBC 
and WBC were determined by the haemocytometer method while ESR was determined using the Westergren method as described by Bain et al. (2012). PCV, HB, RBC, WBC and ESR of non-arthritic/normal group (group 5) were also studied and compared with those of the arthritic/treatment groups.

\subsection{Statistical Analysis}

Data obtained were compared between groups using one way Analysis of Variance (ANOVA). Duncan multiple range tests were used to test for significance differences between means at probability less than 0.05 .

\section{RESULTS}

\subsection{Formaldehyde-Induced Arthritis}

The effect of $S$. tragacantha extract on formaldehyde induced arthritis is summarized in Table 1. The results showed that mean paw thickness of 300 and $100 \mathrm{mg} \mathrm{kg}^{-1}$ STEX groups were significantly $(\mathrm{p}<0.05)$ lower than that of normal saline group. Mean WBC of 100 and $300 \mathrm{mg}$ $\mathrm{kg}^{-1}$ STEX groups were significantly $(\mathrm{p}<0.05)$ lower than that of normal saline group (Table 2). Mean MDA levels of normal saline and $100 \mathrm{mg} \mathrm{kg}^{-1}$ STEX groups were significantly $(\mathrm{p}<0.05)$ higher than MDA levels of non-arthritic and $300 \mathrm{mg} \mathrm{kg}^{-1}$ STEX groups. MDA levels of $300 \mathrm{mg} \mathrm{kg}^{-1}$ STEX and piroxicam groups were similar to that of non-arthritic group (Table 3). Mean SOD levels of 300 and $100 \mathrm{mg} \mathrm{kg}^{-1}$ STEX groups were significantly $(\mathrm{p}<0.05)$ higher than SOD level of normal saline group. Mean catalase level of 100 and $300 \mathrm{mg}$ $\mathrm{kg}^{-1}$ STEX groups were significantly $(\mathrm{p}<0.05)$ higher compared to that of normal saline group (Table 3 ).

\subsection{Complete Freund Adjuvant-Induced Arthritis}

Mean paw thickness of $300 \mathrm{mg} \mathrm{kg}^{-1}$ STEX group was significantly $(p<0.05)$ least from day 7 of the study (Table 4) while the joint diameter was significantly $(p<0.05)$ least in $300 \mathrm{mg} \mathrm{kg}^{-1}$ STEX group from day 14 (Table 5). Mean HB of piroxicam group was significantly $(\mathrm{p}<0.05)$ lower than those of normal, $300 \mathrm{mg} \mathrm{kg}^{-1}$ STEX and $100 \mathrm{mg} \mathrm{kg}^{-1}$ STEX groups (Table 6). Mean WBC of 100 and $300 \mathrm{mg} \mathrm{kg}^{-1}$ STEX groups were significantly $(p<0.05)$ lower than WBC obtained in the normal group (Table 6). Mean ESR of normal saline and $100 \mathrm{mg} \mathrm{kg}^{-1}$ STEX groups were significantly $(\mathrm{p}>0.05)$ faster than ESR of $300 \mathrm{mg}$ $\mathrm{kg}^{-1}$ STEX group (Table 6).

Table 1. Effect of S. tragacantha extract on changes in paw thickness during formaldehyde induced arthritis

\begin{tabular}{|c|c|c|c|c|}
\hline \multirow[b]{2}{*}{ Groups } & \multicolumn{4}{|c|}{ Mean paw thickness (mm) } \\
\hline & Day 0 & Day 3 & Day 7 & Day 14 \\
\hline 1 & $0.42 \pm 0.01$ & $0.59 \pm 0.01^{\mathrm{a}}$ & $0.52 \pm 0.02^{\mathrm{a}}$ & $0.49 \pm 0.02^{\mathrm{a}}$ \\
\hline 2 & $0.44 \pm 0.01$ & $0.62 \pm 0.03^{\mathrm{a}}$ & $0.56 \pm 0.03^{\mathrm{a}}$ & $0.51 \pm 0.02^{\mathrm{a}}$ \\
\hline 3 & $0.44 \pm 0.01$ & $0.65 \pm 0.02^{\mathrm{a}}$ & $0.57 \pm 0.03^{\mathrm{a}}$ & $0.51 \pm 0.01^{\mathrm{a}}$ \\
\hline 4 & $0.45 \pm 0.01$ & $0.78 \pm 0.04^{\mathrm{b}}$ & $0.84 \pm 0.02^{\mathrm{b}}$ & $0.78 \pm 0.06^{\mathrm{b}}$ \\
\hline
\end{tabular}

Group 1 = formaldehyde $+300 \mathrm{mg} \mathrm{kg}^{-1}$ STEX; group $2=$ formaldehyde $+100 \mathrm{mg} \mathrm{kg}^{-1}$ STEX; group $3=$ formaldehyde $+5 \mathrm{mg} \mathrm{kg}^{-1}$ piroxicam; group 4 = formaldehyde + normal saline. Different superscripts ${ }^{\mathrm{a}, \mathrm{b}}$ in a column show significant difference

Table 2. White blood cell counts in S. tragacantha and piroxicam treated rats during formaldehyde-induced arthritis

\begin{tabular}{|c|c|c|c|c|}
\hline \multirow[b]{2}{*}{ Groups } & \multicolumn{4}{|c|}{ WBC $\left(10^{9} / \mathrm{uL}\right)$} \\
\hline & Day 0 & Day 3 & Day 7 & Day 10 \\
\hline 1 & $6.70 \pm 0.10$ & $07.80 \pm 0.10^{\mathrm{a}}$ & $07.00 \pm 0.10^{b}$ & $6.80 \pm 0.20^{\mathrm{b}}$ \\
\hline 2 & $6.20 \pm 0.30$ & $07.70 \pm 0.50^{\mathrm{a}}$ & $08.70 \pm 0.30^{c}$ & $8.50 \pm 0.30^{c}$ \\
\hline 3 & $6.90 \pm 0.50$ & $06.90 \pm 0.90^{\mathrm{a}}$ & $04.70 \pm 0.50^{\mathrm{d}}$ & $4.60 \pm 0.40^{\mathrm{d}}$ \\
\hline 4 & $6.50 \pm 0.60$ & $12.50 \pm 0.10^{\mathrm{b}}$ & $15.10 \pm 0.20^{\mathrm{a}}$ & $14.10 \pm 0.10^{\mathrm{a}}$ \\
\hline
\end{tabular}

Group 1 = formaldehyde $+300 \mathrm{mg} \mathrm{kg}^{-1}$ STEX; group $2=$ formaldehyde $+100 \mathrm{mg} \mathrm{kg}^{-1} \mathrm{STEX}$; group $3=$ formaldehyde $+5 \mathrm{mg} \mathrm{kg}^{-1}$ piroxicam; group $4=$ formaldehyde + normal saline. Different superscripts ${ }^{\mathrm{a}, \mathrm{b}}$ in a column show significant difference 
Udegbunam Rita Ijeoma et al. / American Journal of Pharmacology and Toxicology 9 (2): 107-113, 2014

Table 3. Malondialdehyde (MDA), Superoxide Dismutase (SOD) and Catalase (CAT) levels in paw tissues during formaldehydeinduced arthritis

\begin{tabular}{llcc}
\hline Groups & MDA (nmoL/g tissue) & SOD (units/g tissue) & Catalase (units/g tissue) \\
\hline 1 & $04.35 \pm 0.69^{\mathrm{a}}$ & $214.10 \pm 1.50^{\mathrm{c}}$ & $20.60 \pm 2.22^{\mathrm{c}}$ \\
2 & $18.50 \pm 2.99^{\mathrm{b}}$ & $131.30 \pm 2.02^{\mathrm{b}}$ & $11.10 \pm 0.98^{\mathrm{b}}$ \\
3 & $07.40 \pm 1.23^{\mathrm{a}}$ & $251.50 \pm 3.60^{\mathrm{d}}$ & $23.00 \pm 2.68^{\mathrm{c}}$ \\
4 & $69.80 \pm 10.77^{\mathrm{c}}$ & $085.10 \pm 2.60^{\mathrm{a}}$ & $00.22 \pm 0.03^{\mathrm{a}}$ \\
5 & $02.40 \pm 0.60^{\mathrm{a}}$ & $261.40 \pm 3.90^{\mathrm{d}}$ & $27.40 \pm 2.43^{\mathrm{d}}$ \\
\hline
\end{tabular}

Group $1=$ formaldehyde $+300 \mathrm{mg} \mathrm{kg}^{-1}$ STEX; group $2=$ formaldehyde $+100 \mathrm{mg} \mathrm{kg}^{-1} \mathrm{STEX}$; group $3=$ formaldehyde $+5 \mathrm{mg} \mathrm{kg}^{-1}$ piroxicam; group $4=$ formaldehyde + normal saline; group $5=$ non-arthritic. Different superscripts ${ }^{\mathrm{a}, \mathrm{b}}$ in a column show significant difference

Table 4. Effect of S. tragacantha extract and piroxicam on changes in paw thickness during adjuvant-induced arthritis

\begin{tabular}{|c|c|c|c|c|c|c|}
\hline \multirow[b]{2}{*}{ Groups } & \multicolumn{6}{|c|}{ Mean paw thickness (mm) } \\
\hline & Day 0 & Day 3 & Day 7 & Day 14 & Day 21 & Day 28 \\
\hline 1 & $0.43 \pm 0.02$ & $0.39 \pm 0.01$ & $0.65 \pm 0.09^{\mathrm{a}}$ & $0.61 \pm 0.21^{\mathrm{a}}$ & $0.57 \pm 0.05^{b}$ & $0.53 \pm 0.03^{b}$ \\
\hline 2 & $0.42 \pm 0.04$ & $0.42 \pm 0.03$ & $0.95 \pm 0.22^{\mathrm{b}}$ & $0.87 \pm 0.12^{\mathrm{b}}$ & $0.79 \pm 0.04^{\mathrm{a}}$ & $0.71 \pm 0.0^{\mathrm{a}}$ \\
\hline 3 & $0.44 \pm 0.01$ & $0.40 \pm 0.06$ & $0.90 \pm 0.22^{\mathrm{ab}}$ & $0.75 \pm 0.05^{\mathrm{b}}$ & $0.61 \pm 0.03^{\mathrm{b}}$ & $0.45 \pm 0.05^{\mathrm{b}}$ \\
\hline 4 & $0.45 \pm 0.01$ & $0.43 \pm 0.04$ & $0.90 \pm 0.00^{\mathrm{ab}}$ & $0.95 \pm 0.20^{\mathrm{bc}}$ & $0.85 \pm 0.00^{\mathrm{a}}$ & $0.79 \pm 0.04^{\mathrm{a}}$ \\
\hline
\end{tabular}

Group $1=\mathrm{CFA}+300 \mathrm{mg} \mathrm{kg}^{-1}$ STEX; group 2=CFA+100 $\mathrm{mg} \mathrm{kg}^{-1}$ STEX; group $3=\mathrm{CFA}+5 \mathrm{mg} \mathrm{kg}^{-1}$ piroxicam; group $4=\mathrm{CFA}+$ normal saline. Different superscripts ${ }^{\mathrm{a}, \mathrm{b}}$ in a column show significant difference

Table 5. Effect of S. tragacantha extract and piroxicam on changes in tarso-metatarsal joint thickness during adjuvant-induced arthritis Mean joint thickness (mm)

\begin{tabular}{lllllll} 
Groups & Day 0 & Day 3 & Day7 & Day 14 & Day 21 & Day 28 \\
\hline 1 & $0.65 \pm 0.08$ & $0.65 \pm 0.05$ & $1.07 \pm 0.47$ & $0.80 \pm 0.11^{\mathrm{a}}$ & $0.55 \pm 0.20^{\mathrm{a}}$ & $0.50 \pm 0.10^{\mathrm{a}}$ \\
2 & $0.68 \pm 0.05$ & $0.75 \pm 0.05$ & $1.11 \pm 0.47$ & $1.05 \pm 0.13^{\mathrm{b}}$ & $0.98 \pm 0.21^{\mathrm{cd}}$ & $0.76 \pm 0.30^{\mathrm{b}}$ \\
3 & $0.67 \pm 0.07$ & $0.68 \pm 0.10$ & $1.50 \pm 0.00$ & $0.87 \pm 0.05^{\mathrm{ab}}$ & $0.69 \pm 0.03^{\mathrm{ab}}$ & $0.58 \pm 0.20^{\mathrm{a}}$ \\
4 & $0.70 \pm 0.09$ & $0.78 \pm 0.11$ & $1.35 \pm 0.21$ & $0.96 \pm 0.04^{\mathrm{ab}}$ & $0.90 \pm 0.02^{\mathrm{c}}$ & $0.82 \pm 0.10^{\mathrm{c}}$ \\
\hline
\end{tabular}

Group 1 = CFA +300 $\mathrm{mg} \mathrm{kg}^{-1}$ STEX; group $2=\mathrm{CFA}+100 \mathrm{mg} \mathrm{kg}^{-1}$ STEX; group $3=\mathrm{CFA}+5 \mathrm{mg} \mathrm{kg}^{-1}$ piroxicam; group $4=\mathrm{CFA}+$ normal saline. Different superscripts ${ }^{\mathrm{a}, \mathrm{b}}$ in a column show significant difference

Table 6. Haematologic parameters of rats treated with $S$. tragacantha extract and piroxicam during adjuvant-induced arthritis

\begin{tabular}{llllll}
\hline Groups & PCV $(\%)$ & $\mathrm{HB}(\mathrm{g} / \mathrm{dL})$ & $\mathrm{RBC}\left(10^{3} / \mu \mathrm{L}\right)$ & $\mathrm{WBC}\left(10^{9} / \mu \mathrm{L}\right)$ & $\mathrm{ESR}(\mathrm{mm} / \mathrm{hr})$ \\
\hline 1 & $43.30 \pm 1.80^{\mathrm{ab}}$ & $13.97 \pm 0.20^{\mathrm{b}}$ & $6.05 \pm 0.20^{\mathrm{ab}}$ & $11.05 \pm 1.28^{\mathrm{a}}$ & $2.50 \pm 1.00^{\mathrm{a}}$ \\
2 & $43.00 \pm 1.00^{\mathrm{ab}}$ & $13.40 \pm 0.20^{\mathrm{b}}$ & $5.58 \pm 0.42^{\mathrm{ab}}$ & $15.00 \pm 1.90^{\mathrm{a}}$ & $4.50 \pm 0.50^{\mathrm{b}}$ \\
3 & $38.50 \pm 4.90^{\mathrm{a}}$ & $10.30 \pm 1.50^{\mathrm{a}}$ & $4.53 \pm 0.60^{\mathrm{a}}$ & $09.98 \pm 2.30^{\mathrm{a}}$ & $1.80 \pm 0.70^{\mathrm{a}}$ \\
4 & $42.00 \pm 0.00^{\mathrm{ab}}$ & $13.45 \pm 0.55^{\mathrm{b}}$ & $5.87 \pm 0.14^{\mathrm{ab}}$ & $28.13 \pm 2.40^{\mathrm{b}}$ & $6.00 \pm 0.50^{\mathrm{c}}$ \\
5 & $47.30 \pm 0.88^{\mathrm{b}}$ & $14.60 \pm 0.20^{\mathrm{b}}$ & $6.69 \pm 0.13^{\mathrm{b}}$ & $08.30 \pm 8.80^{\mathrm{a}}$ & $1.30 \pm 0.33^{\mathrm{a}}$ \\
\hline
\end{tabular}

Group 1 = CFA +300 mg kg ${ }^{-1}$ STEX; group $2=\mathrm{CFA}+100 \mathrm{mg} \mathrm{kg}^{-1}$ STEX; group $3=\mathrm{CFA}+5 \mathrm{mg} \mathrm{kg}^{-1}$ piroxicam; group $4=\mathrm{CFA}+$ normal saline; group $5=$ non-arthritic. Different superscripts ${ }^{\mathrm{a}, \mathrm{b}}$ in a column show significant difference.

\section{DISCUSSION}

The inflammatory process is a physiologic response of a living organism to factors such as infection, trauma or immunological mechanisms (Tanas et al., 2010). This process is initiated by the host to eliminate irritants and to set the stage for tissue repair (Bhitre et al., 2008). In this study, arthritis, a chronic joint inflammatory disease, was induced in rats using formaldehyde and Complete Freund's Adjuvant (CFA). Formaldehyde injection elicits localized inflammation and pain in the early phase followed subsequently by a phase of tissue mediated response (Aceto and Cowan, 1991). This late phase produces proliferative joint inflammation leading to articular changes similar to those seen in rheumatoid arthritis (Okoli et al., 2008). CFA on the other hand initiates progressive joint destructi on characterized by synovitis, polyarthritis and systemic infl ammation (Woode et al., 2009). Thus, formaldehyde and CFAinduced arthritis are commonly used experimental models 
for preclinical screening of non-steroidal anti-inflammatory drugs, disease modifying anti-rheumatoid drugs and plant extracts for anti-arthritic effect (Woode et al., 2009). The results obtained in this study showed that STEX significantly suppressed formaldehyde and CFA-induced arthritis as shown by the significantly lesser paw and joint thickness in $300 \mathrm{mg} \mathrm{kg}^{-1}$ STEX group post arthritis induction. However, measurement of paw and joint thickness gives only an indication of edematous changes in these regions (Woode et al., 2009), therefore to correlate the edematous changes with the local biochemical changes, tissue MDA, SOD and catalase level activities in rat paw were measured during formaldehyde-induced arthritis.

Phagocytes such as macrophages and neutrophils which invade inflamed tissues generate reactive oxygen species (Valko et al., 2006). ROS apart from being defensive, when in excess deregulate cellular function causing oxidative damage which worsens inflammation (Wu et al., 2006; Tanas et al., 2010). Cells contain a number of anti-oxidants such as superoxide dismutase, catalase and glutathione peroxidase which prevent the damage caused by ROS (Weydert and Cullen, 2010). SOD converts superoxide radical to hydrogen peroxide and oxygen while catalase decomposes hydrogen peroxide into water (Weydert and Cullen, 2010). In this study, SOD and catalase levels of normal saline and $100 \mathrm{mg} \mathrm{kg}^{-1}$ groups were significantly lower than that of non-arthritic rats. Earlier studies have shown that SOD and catalase levels decreased in chronic inflammatory states (Halici et al., 2007; Wu et al., 2006; Govindarajan et al., 2007). Thus we can infer that the presence of formaldehyde in the tissues stimulated a profuse production of ROS which significantly overwhelmed the antioxidant system in rat paw tissues leading to the decrease in SOD level. However, SOD and catalase levels in the paws of rats treated with $300 \mathrm{mg} \mathrm{kg}^{-1}$ STEX were almost similar to that of non-arthritic rats suggesting that severe paw inflammation was attenuated by administration of this treatment. The finding may be linked to the antiinflammatory and free radical scavenging effects of STEX (Udegbunam et al., 2011).

The level of MDA in the tissue is considered a measure of lipid peroxidation which is linked to the production of superoxide radical (Karatas et al., 2003). Increased level of MDA as seen in normal saline group was an indication that the presence of formaldehyde in the tissues stimulated profuse production of free radicals. Increased lipid peroxidation in rat paw tissues following injection of irritants such as carrageenan has been reported (Tanas et al., 2010). Furthermore, the lower MDA level in the $300 \mathrm{mg} \mathrm{kg}^{-1}$ STEX and piroxicam group suggests that both treatments ameliorated the inflammatory process thus dampening the production of free radicals.

In formaldehyde and CFA induced-arthritis, WBC of the normal saline treated rats was higher than those of the other treatment groups. The increase in WBC in all the groups followed the same pattern as the degree of paw inflammation. Previously, leucocytosis and neutrophilia characterized adjuvant-induced arthritis in rats (Franch et al., 1994). White blood cells are important components of the host defense system (Mahgoub et al., 2008) thus the increased WBC seen in this study can be attributed to systemic response of the rats to paw inflammation induced by formaldehyde and Freund adjuvant (Franch et al., 1994). Furthermore, lower WBC in the $300 \mathrm{mg} \mathrm{kg}^{-1}$ STEX group suggests that the extract showed potent antiarthritic effect given that elevated WBC are associated with active inflammation (Kyei, 2012).

PCV, HB and RBC of normal saline and STEX groups were not significantly different from those of non-arthritic rats. Earlier, Kyei (2012) reported that RBC and $\mathrm{HB}$ of rats were not affected post induction of arthritis. However, this author reported a significant increase in ESR during arthritis. Our finding also showed that ESR was significantly faster in normal saline and in $100 \mathrm{mg} \mathrm{kg}^{-1}$ STEX groups but was slower in $300 \mathrm{mg}$ $\mathrm{kg}^{-1}$ STEX group. Therefore, since proteins produced during inflammation cause erythrocytes to stack up in a group leading to faster settling (Kyei, 2012), the elevation of ESR observed in $100 \mathrm{mg} \mathrm{kg}^{-1}$ STEX group showed the presence of high quantity of inflammatory proteins in circulation while the near normal ESR in 300 $\mathrm{mg} \mathrm{kg}{ }^{-1}$ STEX group points to the fact that inflammation was less severe in this group.

\section{CONCLUSION}

This study showed that daily administration of $300 \mathrm{mg}$ $\mathrm{kg}^{-1}$ STEX significantly ameliorated the arthritic process as shown by lesser local (paw edema and tissue anti-oxidant activities) and systemic (WBC and ESR) changes in rats treated with this dose of STEX. No adverse haematologic effects were noted following the use of both doses of STEX. Therefore we conclude that $S$. tragacantha can serve as a good anti-arthritic agent. Further works are on-going to isolate the bio-active compound in this extract and determine its mechanism(s) of action. 


\section{REFERENCES}

Bang, J.S., D.H. Oh, H.M. Choi, B. Sur and S. Lim et al., 2009. Anti-inflammatory and antiarthritic effect of piperine in human interleukin $1 \beta$ stimulated fibroblast-like synoviocytes and in rat arthritis models. Arthitis Res. Ther., 11: 1-9. DOI: 10.1186/ar2662

Bain, B.J., I. Bates, M.A. Laffan and S.M. Lewis, 2012. Basic Haematological Techniques. In: Dacie and Lewis Practical Haematology, Lewis, S.M., B.J. Bain and I. Bates (Eds.), Churchill Livingstone, ISBN-10: 044306377X, pp: 24-32.

Bhitre, M.J., S. Fulmali, M. Kataria, S. Anwikar and H. Kadri, 2008. Anti-inflammatory activity of the fruits of Piper longum Linn. Asian J. Chem., 20: 4357-4360

Buhroo, A.M. and A.N. Baba, 2006. Adverse effects of low dose methotrexate in patients with rheumatoid arthritis. IJPMR, 17: 21-25.

Franch, A., C. Castellote and M. Castell, 1994. Blood lymphocyte subsets in rats with adjuvant arthritis. Annals Rheum. Dis., 53: 461-466. DOI: 10.1136/ard.53.7.461

Goldring, S.R. and M.B. Goldring, 2006. Clinical aspects, pathology and pathophysiology of osteoarthritis . J. Musculoskelet Neuronal Interact, 6: 376-378. PMID: 17185832

Govindarajan, R., M. Vijayakumar, C.V. Rao, A. Shirwaikar and S. Kumar et al., 2007. Antiinflammatory and antioxidant activities of Desmodium gangeticum fractions in carrageenaninduced inflamed rats. Phytotherapy Res., 21: 975979. DOI: $10.1002 /$ ptr.2199

Halici, Z., G.O. Dengiz, F. Odabasoglu, H. Suleyman and E. Cadirci et al., 2007. Amiadorane has antiinflammatory and anti-oxidative properties: An experimental study in rats with carrageenan-induced paw edema. Eur. J. Pharmacol., 566: 215-221. DOI: 10.1016/j.ejphar.2007.03.046

Halliwell, R.E.W. and N.T. Gorman, 1989. ImmuneMediated Joint Diseases. In: Veterinary Clinical Immunology, Halliwell, R.E.W. and N.T. Gorman, (Eds.), W.B Saunders Co. Philadelphia, ISBN-10: 0721611974, pp: 337-358.

Hegen, M., J.C. Keith, M. Collins and C.J. NickersonNutter, 2008. Utility of animal models for identification of potential therapeutics for rheumatoid arthritis. Annals Rheumatic Dis., 67: 1505-1515. DOI: 10.1136/ard.2007.076430
Iwu, M.M., 1993. Handbook of African Medicinal Plants. Ist Edn., CRC Press Boca Raton, FL, ISBN-10: 084934266X, pp: 464.

Josheph, B. and S.J. Raj, 2010. Pharmacognostic and pharmacology properties of Aloe vera. Int. J. Pharmaceutical Sci. Rev. Res., 4: 106-109.

Kahn, C.M., 2005. Immunopathological Diseases. In: Merck Veterinary Manual, Merck and Co Ltd., Whitehouse station, N.J, USA, ISBN-10: 091191093X.

Kaithwas, G. and D.K. Majumdar, 2010. Therapeutic effect of Linum usitatissimum (flaxseed/linseed) fixed oil on acute and chronic arthritic models in albino rats. Inflammopharmacology, 18: 127-136. DOI: $10.1007 / \mathrm{s} 10787-010-0033-9$

Karatas, F., I. Ozates, H. Canatan, I. Halifeoglu and M. Karatepe et al., 2003. Antioxidant status and lipid peroxidation in patients with rheumatoid arthritis. Ind. J. Med. Res., 118:178-181. PMID: 14700353

Kaur, A., P. Nain and J. Nain, 2012. Herbal plants used in treatment of rheumatoid arthritis: A review intern. J. Pharm. Pharmaceut. Sci., 4: 44-57

Kyei, S., 2012. Anti-inflammatory, anti-pyretic and safety assessment of aqueous and methanolic leaf extracts of Pistia stratiotes Linn (Araceae). MSc Thesis, Kwame Nkrumah University of Science and Technology.

Kyei, S., G.A. Koffuor and J.N.B. Pong, 2012. The efficacy of aqueous and methanolic leaf extracts of Pistia stratoites linn in management of arthritis and fever. J. Med. Biomedical Sci., 1: 29-37. DOI: 10.4314\%2Fjmbs.v1i2

Lin, C.R., F. Amaya, L. Barrett, H. Wang and J. Takada et al., 2006. Prostaglandin $\mathrm{E}_{2}$ receptor $\mathrm{EP}_{4}$ contributes to inflammatory pain hypersensitivity. J. Pharmacol. Exp. Theraprut., 319: 1096-1103. DOI: 10.1124/jpet.106.105569

Mahajan, N., J. Kaur, S. Rawal, A. Sharma and K. Sen et al., 2010. Adult rheumatoid arthritis-a review. Intern J. Pharm. Res. Dev., 2:1-9

Mahgoub, O., I.T. Kadim, M.H. Tageldin, W.S. AlMazooqui and S.Q. Khalaf et al., 2008. Clinical profile of sheep fed non-conventional feeds containing phenols and condensed tannins. Small Rumnant Res., 78:115-122. DOI: 10.1016/j.smallrumres.2008.05.009

Makinen, H., H. Kautianinen, P. Hannonen, M. Mottonen and M. Leirisalo-Repo et al., 2007. Sustained remission and reduced radiographic progression with combination disease modifying anti-rheumatic drugs in early rheumatoid arthritis. J. Rheumatol., 34: 316-321. PMID: 17183623 
Mottonen, T., P. Hannonen, M.L. Repo, M. Korpela and M. Hakala et al., 2006. Efficacy of combination therapy on rheumatoid arthritis: Comments on the review by Smolen et al. Arthritis Rheumatol., 54: 2032-2034. DOI: 10.1002/art.21915

Newbould, B.B., 1963. Chemotherapy of arthritis induced in rats by Mycobacterial adjuvant. British J. Pharmacol. Chemotherapy, 21: 127-136. DOI: 10.1111/j.1476-5381.1963.tb01508.x

Ohkawa, H., H. Ohishi and K. Yagi, 1979. Assay for lipid peroxide in animal tissues by thiobarbituric acid reaction. Analystical Biochem., 95: 351-358. DOI: 10.1016/0003-2697(79)90738-3

Okoli, C.O., P.A. Akah, A.C. Ezike, S.O. Udegbunam and S.C. Nworu et al., 2008. Ethnobiology and Pharmacology of Jatropha Curcas. L. In: Ethnopharmacology, Akah, P.A. (Ed.), Research Signpost, India, ISBN-10: 978-81-308-0252-7, pp: 101-125.

Ruggiero, C., F. Lattanzio, F. Lauretani, B. Gasperini and C. Andres-Lacueva et al., 2009. Omega-3 polyunsaturated fatty acids and immune-mediated diseases: Inflammatory bowel disease and rheumatoid arthritis. Curr. Pharm. Des., 15: 41354148. DOI: $10.2174 / 138161209789909746$

Seyle, H., 1949. Further studies concerning the participation of adrenal cortex in the pathogenesis of arthritis. British Med. J., 2: 1129-1135. PMID: 15396087

Sinha, K.A., 1972. Colorimetric assay of catalase. Analytical Biochem., 47: 389-394. DOI: 10.1016/0003-2697(72)90132-7

Sun, Y., L.W. Oberley and Y. Li, 1988. A simple method for clinical assay of superoxide dismutase. Clinical Chem., 34: 497-500. PMID: 3349599

Tanas, S., F. Odabasoglu, Z. Halici, A. Cakir and H. Aygun et al., 2010. Evaluation of anti-inflammatory and anti-oxidant activities of Peltigera rufescens lichen species in acute and chronic inflammation models. J. Natural Med., 64: 42-49. DOI: $10.1007 / \mathrm{s} 11418-009-0367-\mathrm{z}$
Todhunter, R.J. and S.A. Johnston, 2003. Osteoarthritis. In: Textbook of Small Animal Surgery, Slatter, D. (Ed.), Saunders, pp: 2208-2046.

Udegbunam, R.I, I.U. Asuzu, R.O.C. Kene, S.O. Udegbunam and C. Nwaehujor, 2011. Antinociceptive, anti-inflammatory and antioxidant effects of the methanol extract of Sterculia tragcantha Lindl. J. Pharmacol. Toxicol., 6: 516-524.

Vaidya, A.D.B., 2006. Reverse pharmacological correlates of ayurvedic drug action. Ind. J. Pharmacol., 38: 311-315. DOI: 10.4103/02537613.27697

Valko, M., C.J. Rhodes, J. Moncol, M. Izakovic and M. Mazur, 2006. Free radicals, mental and antioxidants in oxidation stress-induced cancer. ChemicoBiolical Interact., 160: 1-40. DOI: 10.1016/j.cbi.2005.12.009

Weydert, C.J. and J.J. Cullen, 2010. Measurement of superoxide dismutase, catalase and glutathione peroxidase in cultured cells and tissues. Nature Protocols, 5: 51-66. DOI: 10.1038/nprot.2009.197

Aceto, W.H. and A. Cowan, 1991. Neurogenic and tissue-mediated components of formalin-induced edema: Evidence for supraspinal regulation. Agents Actions, 34: 264-269. DOI: 10.1007/BF01993299

Woode, E., E.B. Gyasi, C.A. Danquah, C. Ansah and M. Duwiejua, 2009. Anti-arthritic effects of Palisota hirsuta K. Schum. Leaf extract in Freund adjuvantinduced arthritis in rats. Int. J. Pharmacol., 5: 181190. DOI: 10.3923/ijp.2009.181.190

Wu, Y., C. Zhou, L. Song, X. Li and S. Shi et al., 2006. Effect of total phenolics from Laggera alata on acute and chronic inflammation models. J. Ethnopharmacol., 108: 243-250. DOI: 10.1016/j.jep.2006.05.017

Zhao, H., S. Liu, D. Huang, Q. Xu and T. Shuto et al., 2006. The protective effects of incadronate on inflammation and joint destruction in established rat adjuvant arthritis. Rheumatol. Int., 26: 732-740. DOI: $10.1007 / \mathrm{s} 00296-005-0061-8$ 